\title{
Preparation of iPSCs for targeted proteomic analysis
}

Anna Baud(1), Wendy E. Heywood(1), Daniel Little(2), Paul Gissen(2) and Kevin Mills(1).

Affiliations: (1) Centre for Translational Omics, UCL Institute of Child Health, 30 Guilford Street, London, UK, (2) MRC Laboratory for Molecular Cell Biology, University College London, London, UK

\begin{abstract}
Induced pluripotent stem cells have great potential as a human model system in regenerative medicine, disease modelling and drug screening. However, extensive analysis of iPSC are required before their therapeutic applications. With recent developments in mass spectrometry and proteomics, this technique can become a great alternative to traditional genomic approaches for iPSC analysis. Here, we describe preparation of iPSC for targeted proteomic analysis, and measurement of pluripotency markers allowing for classification into either pluripotent or non-pluripotent cells.
\end{abstract}

\section{Keywords}

Induced pluripotent stem cells, pluripotency, proteomics, mass spectrometry

\section{Introduction}

Induced pluripotent stem cells (iPS cells) are somatic cells which acquire properties similar to the embryonic stem cells ${ }^{1}$. There are multiple ways to generate iPSCs: retroviral transfection of transcription factors OCT4, SOX-2, c-MYC and KLF-42, plasmids $^{3}$, non-integrating viruses (Sendai virus $)^{4,5}$, drug-inducible systems ${ }^{6}$, transposition ${ }^{7}$, protein transduction ${ }^{8}$ or mature microRNAs ${ }^{9}$. Yet, despite different techniques available, the reprogramming process yields low number of iPS cells and there is a need for an assay able to distinguish between pluripotent and non-pluripotent cells. Several assays for iPSC quality control are available: visualization of colony-morphology using light microscopy or extracellular marker staining, embryoid body or teratoma formation, as well as assays based on gene expression, i.e. PluriTest ${ }^{10}$ or ScoreCard ${ }^{11}$. However these tests have major drawbacks, such as long performance time and significant cost.

With recent advances in targeted mass spectrometry, this technique is now enabling fast, reliable and absolute quantitation of proteins of interest, and supports not only basic, but also clinical research ${ }^{12,13}$. Taking advantage of that, and in order to increase the simplicity and efficiency of iPSCs characterization, we have developed a peptide based multiple reaction monitoring-mass spectrometry assay (MRM-LC-MS/MS) ${ }^{14}$. In this assay, iPS cell pellets are digested and resulting peptides are analyzed by UPLC-MS/MS (Figure 1). At the first stage of method development, the list of potential pluripotency biomarkers was determined from the literature and current pluripotency tests (staining markers and self-renewal markers included in ScoreCard assay). Then, after sample preparation and analytical method refinement, the expression of five proteins: OCT4, SOX-2, LIN28, PODXL and CD44 were demonstrated as being able to discriminate between pluripotent and non-pluripotent cells. The pluripotency signature measured by the mass spectrometry was confirmed by the generation of three-germ layer embryonic bodies and the successful terminal differentiation of these clones into neuronal cells ${ }^{15,16}$.

To summarize, a simple and high-throughput measurement of pluripotency signature can be achieved using as little as 200,000 cells by means of targeted mass spectrometry. Moreover, this assay is significantly simpler and faster than conventional genomic tests. Our test can be implemented in any laboratory, which has access and expertise in using triple quadrupole mass spectrometers and this method can be easily amended for measuring other proteins of interest in iPSC pellets, based on literature search or mass spectrometry discovery experiments. 


\section{Materials}

Prepare all solutions using ultrapure water (prepared by purifying deionized water, to attain a sensitivity of $18 \mathrm{M} \Omega-\mathrm{cm}$ at $25{ }^{\circ} \mathrm{C}$ ) and analytical and mass spectrometry grade reagents. Prepare and store all reagents at room temperature (unless indicated otherwise).

1. Standard peptides:

a. The list of quantotypic peptides selected for pluripotency test is given in Table 1. (Note 1)

b. 50:50 (v:v) acetonitrile $\left(\mathrm{CH}_{3} \mathrm{CN}\right) / \mathrm{H}_{2} \mathrm{O}$

2. Standard isotope labelled (SIL) analog of standard peptide:

a. The list of SIL peptides selected for pluripotency test is given in Table 1. (Note 2)

3. iPS cell harvest

a. $0.5 \mathrm{M}$ EDTA $\mathrm{pH} 8.0$, diluted to $0.5 \mathrm{mM}$ in PBS

b. PBS

4. Digestion:

a. Digestion buffer: $100 \mathrm{mM}$ Tris $\mathrm{HCl}, 6 \mathrm{M}$ Urea, 2M Thiourea, 2\% ASB-14.

b. DL-dithiothreitol (DTT): $30 \mathrm{mg} / \mathrm{mL}$ in $100 \mathrm{mM}$ Tris, $\mathrm{pH}$ 7.8. (Note 3)

c. Iodoacetamide (IAA): $36 \mathrm{mg} / \mathrm{mL}$ in $100 \mathrm{mM}$ Tris, $\mathrm{pH}$ 7.8. Protect from light. (Note 4)

d. Sequencing grade modified trypsin: $0.1 \mu \mathrm{g} / \mu \mathrm{l}$ in $50 \mathrm{mM}$ ammonium bicarbonate buffer $\mathrm{pH}$ 7.8. Store at -20 before ready to use.

5. Solid Phase Exchange (SPE):

a. Commercially available SPE C18 $100 \mathrm{mg} / 1 \mathrm{~mL}$ column

b. $0.2 \%$ Trifluoroacetic Acid (TFA)

c. $0.1 \%$ TFA

d. $70 \% \mathrm{CH}_{3} \mathrm{CN}$ in $0.1 \%$ TFA

6. Chromatography and Mass Spectrometry:

a. Solvent A: $0.1 \%$ Formic Acid in $\mathrm{dd}_{2} \mathrm{O}$.

b. Solvent B: $0.1 \%$ Formic Acid in $\mathrm{CH}_{3} \mathrm{CN}$.

c. Waters CORTECS UPLC C18 Column, $90 \AA$ A $, 1.6 \mu \mathrm{m}, 2.1 \mathrm{~mm}$ x $50 \mathrm{~mm}$ attached to a C18 VanGuard pre-column

d. Acquity UPLC system (Waters) coupled to a XevoTM TQ-S triple quadrupole mass spectrometer (Waters) equipped with electrospray source.

\section{Methods}

Carry out all procedures at room temperature unless stated otherwise. Always wear gloves to reduce keratin contamination.

1. Preparation of standard peptides and SIL analogs of standard peptides:

a. Resuspend synthetic peptides to $1 \mathrm{mg} / \mathrm{ml}$ stock concentration according to manufactures instructions. By default if instructions are not available, resuspend peptides in 50:50 (v:v) acetonitrile $\left(\mathrm{CH}_{3} \mathrm{CN}\right) / \mathrm{H}_{2} \mathrm{O}$.

b. Prepare the 1:10 dilutions of the peptide from the stock concentration and pool 1000 pmoles of each peptide into a low binding microcentrifuge tube.

c. Prepare several pools of 1000 pmols of SIL analogs of standard peptides.

d. Dry down in a speed-vac concentrator the final pool and store at $-20^{\circ} \mathrm{C}$. Prepare several pools for future use.

e. Resuspend an aliquot of pooled 1000 pmol peptides in digestion buffer to obtain concentrations of $10 \mathrm{pmol} / \mu \mathrm{l}$.

2. iPS cell harvest

a. Warm $0.5 \mathrm{mM}$ EDTA to $37^{\circ} \mathrm{C}$ 
b. Aspirate media from almost confluent well of iPS cells and add PBS to wash cells then immediately aspirate

c. Add warmed $0.5 \mathrm{mM}$ EDTA to cover surface of dish and incubate at $37^{\circ} \mathrm{C}$ for 5 minutes

d. Aspirate EDTA carefully to leave cells attached to dish, pipette PBS around surface of dish approximately 3 times to detach cells

e. Collect detached cells and centrifuge at $300 \mathrm{x}$ g, carefully remove PBS from cell pellet.

3. Digestion:

Typical assay workflow is given in Figure 1.

a. Dissolve harvested cell pellet ( $\sim 2$ million cells/pellet) in $100 \mu \mathrm{L}$ of digestion buffer (Note 5). Vortex well and sonicate for 3 minutes.

b. Add $1 \mu \mathrm{L}$ of $10 \mathrm{pmol} / \mu \mathrm{l}$ SIL analog of standard peptides with trypsin tag. Incubate $1 \mathrm{~h}$.

c. Add $7.5 \mu \mathrm{L}$ of $30 \mathrm{mg} / \mathrm{mL}$ DTT. Incubate for $1 \mathrm{~h}$.

d. Add $15 \mu \mathrm{L}$ of $36 \mathrm{mg} / \mathrm{mL}$ IAA. Incubate for $30 \mathrm{~min}$ in dark. (Note 4)

e. Add $750 \mu \mathrm{L}$ of dd $\mathrm{H}_{2} \mathrm{O}$.

f. Add $58 \mu \mathrm{L}$ of $0.1 \mu \mathrm{g} / \mu \mathrm{l}$ trypsin.

g. Complete with $\mathrm{H}_{2} \mathrm{O}$ to a final volume of $1000 \mu \mathrm{L}$.

h. Incubate in water bath at $37{ }^{\circ} \mathrm{C}$ for $12-16 \mathrm{~h}$.

4. Purification of iPS cell digests using SPE.

a. Take $500 \mu \mathrm{L}$ of digest and mix it thoroughly with $500 \mu \mathrm{L} 0.2 \%$ TFA.

e. Prime the SPE column with $2 \mathrm{~mL}$ of $70 \% \mathrm{CH}_{3} \mathrm{CN}$ in $0.1 \%$ TFA.

f. Prime the SPE column with $2 \mathrm{~mL}$ of $0.1 \%$ TFA.

b. Apply the sample on the column and collect the flow-through.

c. Apply the flow-through on the column.

d. Wash the column with $1 \mathrm{~mL}$ of $0.1 \%$ TFA.

g. Elute peptides with $500 \mu \mathrm{L}$ of $70 \% \mathrm{CH}_{3} \mathrm{CN}$ in $0.1 \%$ TFA.

e. Freeze-dry the peptides.

f. Resuspend peptides in $50 \mu \mathrm{L}$ of Solvent A.

5. LC-MRM Assay.

Typical chromatographic results are given in Figure 2.

a. Transfer purified peptide digests into glass insert vials.

b. Set up analytical UPLC conditions: the flow rate $0.8 \mathrm{~mL} / \mathrm{min}$, and a 7-min linear gradient starting at $100 \%$ solvent, ramping to $40 \%$ solvent B in $3.5 \mathrm{~min}$, then to $99.9 \%$ Solvent B over $0.25 \mathrm{~min}$ (held for $1.5 \mathrm{~min}$ ) and finally decreased to $100 \%$ solvent A in $0.25 \mathrm{~min}$ and reconditioned for $1.5 \mathrm{~min}$.

c. Set up mass spectrometry conditions: positive ion mode, dynamic multiple reaction monitoring with a dwell time set up to automatic, and minimum 8 data points per peak. Transition list for peptides selected for pluripotency test are given in Table 1.

d. Set up sequence of analysed samples, including standard curve, quality controls (QC) and blanks.

e. Inject $10 \mu \mathrm{L}$ of sample per analysis.

6. Standard curve:

Representative standard curves for the pluripotency LC-MRM assay are given in Figure 3.

a. Digest and purify one pooled 1000 pmol aliquot of standard peptides spiked with SIL. After purification, freeze-dry and resuspend peptide standards in Solvent A.

b. Dilute digested standards in Solvent A to the following concentrations: 0, 0.001, 0.005, $0.01,0.05,0.1,0.2,0.5$ and $1 \mathrm{pmol} / \mu \mathrm{L}$.

c. Transfer diluted standards into glass insert vials.

d. Inject $10 \mu \mathrm{L}$ of standard per analysis.

e. Analyse standard peptides using the same LC-MRM method as for samples.

7. Quality control: 
a. Pool $10 \mu \mathrm{L}$ of each sample and spike in your standard peptides, then transfer into glass insert vial.

b. Before analysing samples, inject 3 QC samples to ensure good sensitivity of the instrument.

c. Inject QC samples in intervals between samples, i.e. between every 10 samples.

8. Data analysis:

a. Use Waters MassLynx and TargetLynx V4.1 software to analyse the raw data.

b. Set up a method to ratio integrated peaks to SIL peptide analogs.

c. Verify the automatic integration to ensure accuracy.

d. Interpolate response values from the standard curve.

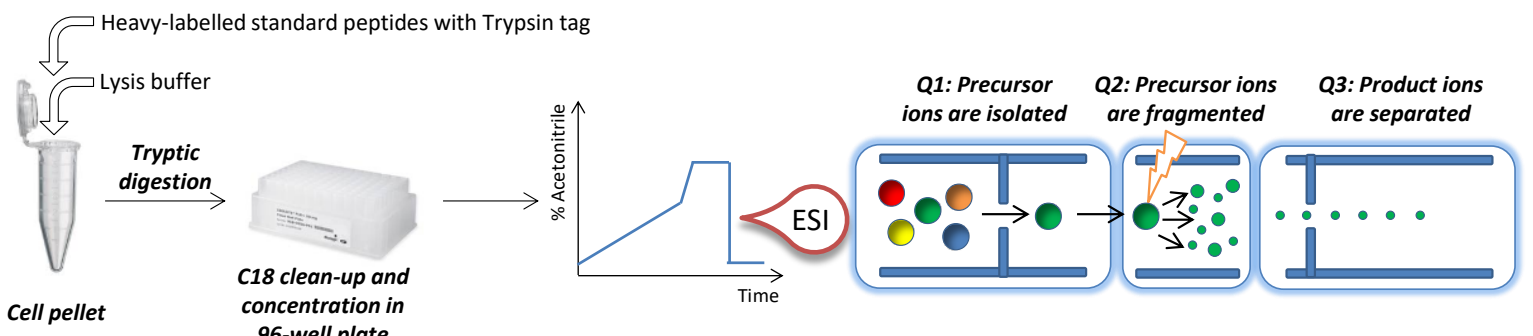

Figure 1. Typical LC-MRM pluripotency assay workflow. Adapted from ${ }^{14}$.
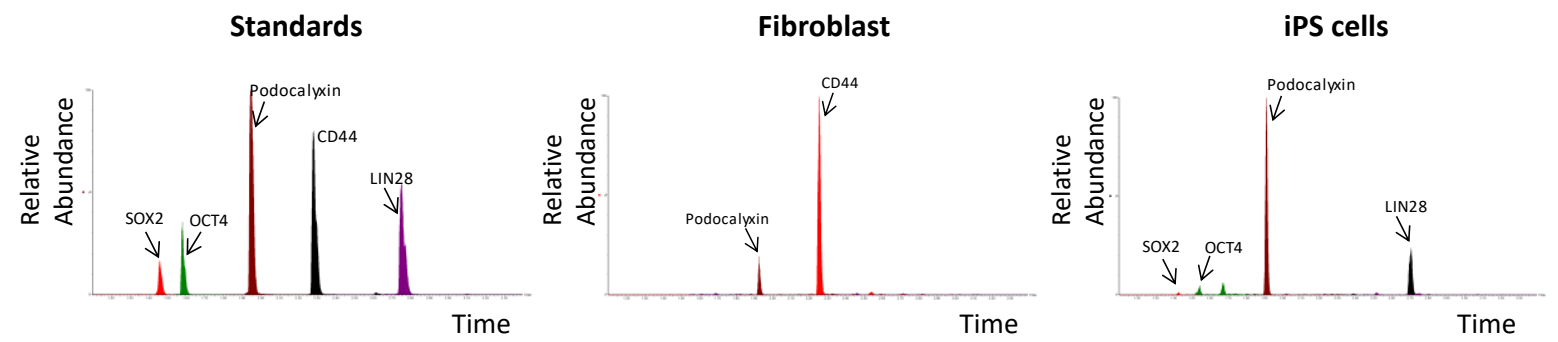

Figure 2. Typical chromatographic results of the LC-MRM pluripotency assay. Adapted from ${ }^{14}$. 

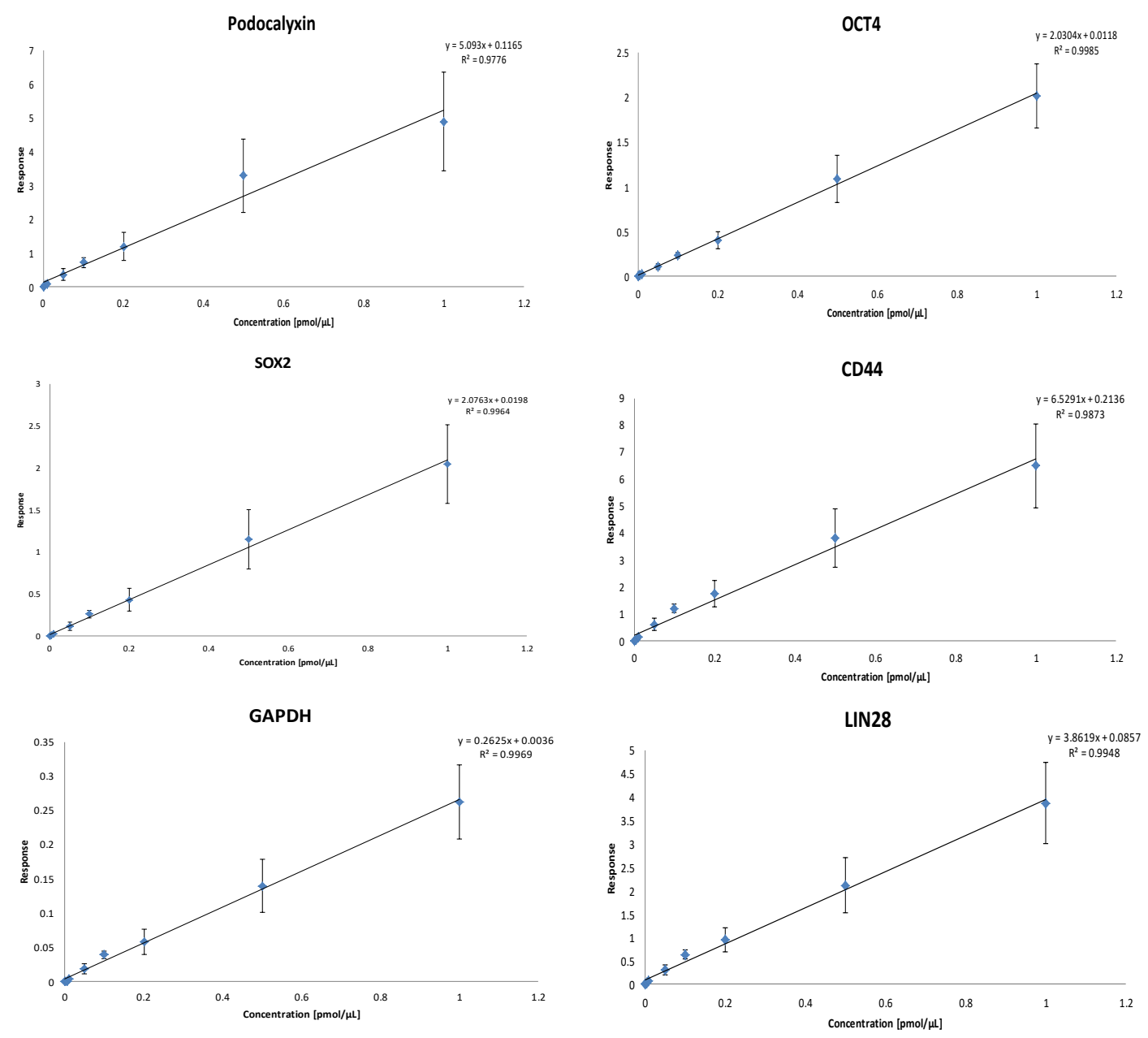

Figure 3. Representative standard curves for the pluripitency LC-MRM assay.

Table 1. List of peptides and transitions selected for the pluripotency test.

\begin{tabular}{|l|l|l|l|l|}
\hline Protein & Peptide & Transition & $\begin{array}{l}\text { Cone } \\
\text { Voltage }\end{array}$ & $\begin{array}{l}\text { Collision } \\
\text { Energy }\end{array}$ \\
\hline LIN28 & AAEEAPEEAPEDAAR & $778.39>1084.28$ & 43 & 20 \\
\hline LIN28 & AAEEAPEEAPEDAAR & $778.39>729.24$ & 43 & 20 \\
\hline LIN28 & MGFGFLSMTAR & $609.41>882.40$ & 58 & 18 \\
\hline LIN28 & MGFGFLSMTAR & $609.41>678.29$ & 58 & 16 \\
\hline LIN28 SIL & MGFGFLSMT[A(13C3;15N)]RAGVA & $611.44>886.61$ & 17 & 22 \\
\hline LIN28 SIL & MGFGFLSMT[A(13C3;15N)]RAGVA & $611.44>686.45$ & 17 & 20 \\
\hline CD44 & LVINSGNGAVEDR & $672.47>904.52$ & 39 & 26 \\
\hline CD44 & LVINSGNGAVEDR & $672.47>566.43$ & 39 & 20 \\
\hline CD44 & YGFIEGHVVIPR & $462.82>612.52$ & 15 & 14 \\
\hline CD44 & YGFIEGHVVIPR & $462.82>510.39$ & 15 & 14 \\
\hline OCT4 & AETLVQAR & $444.34>687.62$ & 34 & 10 \\
\hline OCT4 & AETLVQAR & $444.34>586.32$ & 34 & 14 \\
\hline OCT4 & WVEEADNNENLQEICK & $645.33>847.18$ & 14 & 15 \\
\hline OCT4 & WVEEADNNENLQEICK & $645.33>677.33$ & 16 & 15 \\
\hline OCT4 SIL & AETL[V(13C5; 15N)]QAR & $447.39>693.57$ & 17 & 22 \\
\hline OCT4 SIL & AETL[V(13C5; 15N)]QAR & $447.39>479.36$ & 17 & 22 \\
\hline PODXL & LASVPGSQTVVVK & $643.05>914.66$ & 43 & 20 \\
\hline PODXL & LASVPGSQTVVVK & $643.05>457.87$ & 43 & 20 \\
\hline PODXL & ATFNPAQDK & $496.28>819.56$ & 43 & 16 \\
\hline PODXL & ATFNPAQDK & $496.28>558.36$ & 43 & 18 \\
\hline
\end{tabular}




\begin{tabular}{|l|l|l|l|l|}
\hline SOX-2 & SEASSSPPVVTSSSHSR & $568.06>743.49$ & 2 & 10 \\
\hline SOX-2 & SEASSSPPVVTSSSHSR & $568.06>577.38$ & 2 & 16 \\
\hline SOX-2 & DMISMYLPGAEVPEPAAPSR & $711.1>824.43$ & 34 & 22 \\
\hline SOX-2 & DMISMYLPGAEVPEPAAPSR & $711.1>598.33$ & 34 & 22 \\
\hline SOX-2 SIL & SEASSSPP[V(13C5;15N)]VTSSSHSR & $569.94>623.82$ & 2 & 16 \\
\hline SOX-2 SIL & SEASSSPP[V(13C5;15N)]VTSSSHSR & $569.94>580.31$ & 2 & 16 \\
\hline
\end{tabular}

\section{Notes}

Note 1. Marker peptide should be unique to the protein of interest (proteotypic) and representing the quantitative abundance of the protein (quantotypic). Standard marker peptides can be custom synthetized by various commercial companies.

Note 2. In order to monitor for digestion efficiency, a trypsin tag should be added to the standard peptide sequence. The trypsin tag of 3-5 amino acids can be determined from the sequence of the protein, found in the Uniprot database. SIL peptides with trypsin tag can be custom synthetized by various commercial companies.

Note 3. DTT should be prepared fresh on the day and kept on ice until use.

Note 4. Iodoacetamide is sensitive to light. Protect the stock solution of iodoacetamide and samples containing iodoacetamide from light by wrapping tubes in aluminium foil and keeping them in dark cabinet. Try to manipulate quickly in order to limit exposition to light. The stock solution should be prepared fresh on the day.

Note 5. If 2 million cells are not available, the protocol can be adjusted to the lesser amount of cells, by decreasing the volumes of added reagents during digestion. The minimum of cells required is 200,000 .

\section{Acknowledgements}

The authors declare no competing financial interests. The research leading to these results has received support from the Innovative Medicines Initiative Joint Undertaking under grant agreement $n^{\circ} 115439$, resources of which are composed of financial contribution from the European Union's Seventh Framework Programme (FP7/2007-2013) and EFPIA companies' in kind contribution. All research at Great Ormond Street Hospital NHS Foundation Trust and UCL Great Ormond Street Institute of Child Health is made possible by the NIHR Great Ormond Street Hospital Biomedical Research Centre. The views expressed are those of the authors and not necessarily those of the NHS, the NIHR the Department of Health, IMI JU nor EFPIA nor the European Commission and are not liable for any use that may be made of the information contained therein. The authors would like to gratefully acknowledge the support of Leonard Wolfson and Peto Foundations.

\section{References}

(1) Takahashi, K.; Yamanaka, S. Cell 2006, 126 (4), 663-676.

(2) Takahashi, K.; Tanabe, K.; Ohnuki, M.; Narita, M.; Ichisaka, T.; Tomoda, K.; Yamanaka, S. Cell 2007, 131, 861-872.

(3) Yu, J.; Hu, K.; Smuga-otto, K.; Tian, S.; Stewart, R.; Igor, I.; Thomson, J. A. Science (80-. ). 2009, 324 (5928), 797-801.

(4) Fusaki, N.; Ban, H.; Nishiyama, A.; Saeki, K.; Hasegawa, M. Proc. Jpn. Acad. Ser. B. Phys. Biol. Sci. 2009, 85 (8), 348-362.

(5) Nishimura, K.; Sano, M.; Ohtaka, M.; Furuta, B.; Umemura, Y.; Nakajima, Y.; Ikehara, Y.; Kobayashi, T.; Segawa, H.; Takayasu, S.; Sato, H.; Motomura, K.; Uchida, E.; Kanayasu- 
Toyoda, T.; Asashima, M.; Nakauchi, H.; Yamaguchi, T.; Nakanishia, M. J. Biol. Chem. 2011, 286 (6), 4760-4771.

(6) Hockemeyer, D.; Soldner, F.; Cook, E. G.; Gao, Q.; Mitalipova, M.; Jaenisch, R. Cell Stem Cell 2008, 3, 346-353.

(7) Samavarchi-Tehrani, P.; Golipour, A.; David, L.; Sung, H. K.; Beyer, T. a.; Datti, A.; Woltjen, K.; Nagy, A.; Wrana, J. L. Cell Stem Cell 2010, 7 (1), 64-77.

(8) Kim, D.; Kim, C.; Moon, J.; Chung, Y.; Chang, M.; Han, B.; Ko, S.; Yang, E.; Cha, K. Y.; Lanza, R.; Kim, K. Stem Cell 2009, 4 (6), 472-476.

(9) Miyoshi, N.; Ishii, H.; Nagano, H.; Haraguchi, N.; Dewi, D. L.; Kano, Y.; Nishikawa, S.; Tanemura, M.; Mimori, K.; Tanaka, F.; Saito, T.; Nishimura, J.; Takemasa, I.; Mizushima, T.; Ikeda, M.; Yamamoto, H.; Sekimoto, M.; Doki, Y. Stem Cell 2011, 8 (6), 633-638.

(10) Müller, F.-J.; Schuldt, B. M.; Williams, R.; Mason, D.; Altun, G.; Papapetrou, E. P.; Danner, S.; Goldmann, J. E.; Herbst, A.; Schmidt, N. O.; Aldenhoff, J. B.; Laurent, L. C.; Loring, J. F. Nat. Methods 2011, 8 (4), 315-317.

(11) Tsankov, A. M.; Akopian, V.; Pop, R.; Chetty, S.; Gifford, C. A.; Daheron, L.; Tsankova, N. M.; Meissner, A. Nat. Biotechnol. 2015, 33 (11), 1-15.

(12) Picotti, P.; Aebersold, R. Nat. Methods 2012, 9 (6), 555-566.

(13) Ebhardt, H. A.; Root, A.; Sander, C.; Aebersold, R. Proteomics 2015, 15 (18), 3193-3208.

(14) Baud, A.; Wessely, F.; Mazzacuva, F.; McCormick, J.; Camuzeaux, S.; Heywood, W. E.; Little, D.; Vowles, J.; Tuefferd, M.; Mosaku, O.; Lako, M.; Armstrong, L.; Webber, C.; Cader, M. Z.; Peeters, P.; Gissen, P.; Cowley, S. A.; Mills, K. Anal. Chem. 2017, 89, 2440-2448.

(15) Fernandes, H. J. R.; Hartfield, E. M.; Christian, H. C.; Emmanoulidou, E.; Zheng, Y.; Booth, H.; Bogetofte, H.; Lang, C.; Ryan, B. J.; Sardi, S. P.; Badger, J.; Vowles, J.; Evetts, S.;

Tofaris, G. K.; Vekrellis, K.; Talbot, K.; Hu, M. T.; James, W.; Cowley, S. A.; Wade-Martins, R. Stem Cell Reports 2016, 6, 342-356.

(16) Haenseler, W.; Sansom, S. N.; Buchrieser, J.; Newey, S. E.; Moore, C. S.; Nicholls, F. J.; Chintawar, S.; Schnell, C.; Antel, J. P.; Allen, N. D.; Cader, M. Z.; Wade-martins, R.; James, W. S.; Cowley, S. A. Stem Cell Reports 2017, 8 (6), 1727-1742. 